\title{
A Study on Red Aesthetic Value in the Revolutionary Historical and Cultural Heritage of Shaanxi
}

\author{
Peng Chen \\ School of Art and Design \\ Xi'an University of technology \\ Xi'an, China
}

\begin{abstract}
The revolutionary historical culture of modern China is an important part of contemporary social culture, which affects us as a traditional cultural power. The values and modes of thinking born in a particular historical period determine people's aesthetic tendency for a long time. The contemporary humanistic values of red culture are gradually being recognized by people and it is necessary to probe into and re-recognize them. The red culture produced from the revolutionary history of Shaanxi is the representative of this humanistic spirit, based on this, the fundamental structure of red aesthetics is extracted, which has great significance to interpret the basic forms of contemporary social culture.
\end{abstract}

Keywords-revolutionary history of Shaanxi; red culture; aesthetic value; red aesthetics

\section{INTRODUCTION}

The revolutionary history of Shaanxi holds an extremely high position in the revolutionary history of modern China. The revolutionary base areas in northern Shaanxi, represented by the Red Holy Land Yan'an, have almost become the symbol of history in this period. These cultural achievements constructed by the history in this period have profound impacts on Chinese cultural development process in the past hundred years. After the accumulation by several generations, these red cultures have an irreversible impact on national values, ways of thinking and aesthetic, and have gradually been an important bas is for the spiritual level of Chinese nation.

Literature and art studies centered on this section of revolutionary history have rich cultural value and have produced countless artistic achievements. The humanistic value of red culture has the demand of discussion and re-recognition in contemporary society. The author derives data from the 2017 CNKI literature by searching the theme of "red culture" keywords and obtains 370 relevant literatures. Based on this, the author also carries out the visualized analysis on keyword relevance by Cityspace document analys is tool "Fig. 1". It can be seen that the current application and research on red culture mainly focus on these aspects of ideological education, touris m and cultural resources, but the research on aesthetics in the cultural system is obviously insufficient.

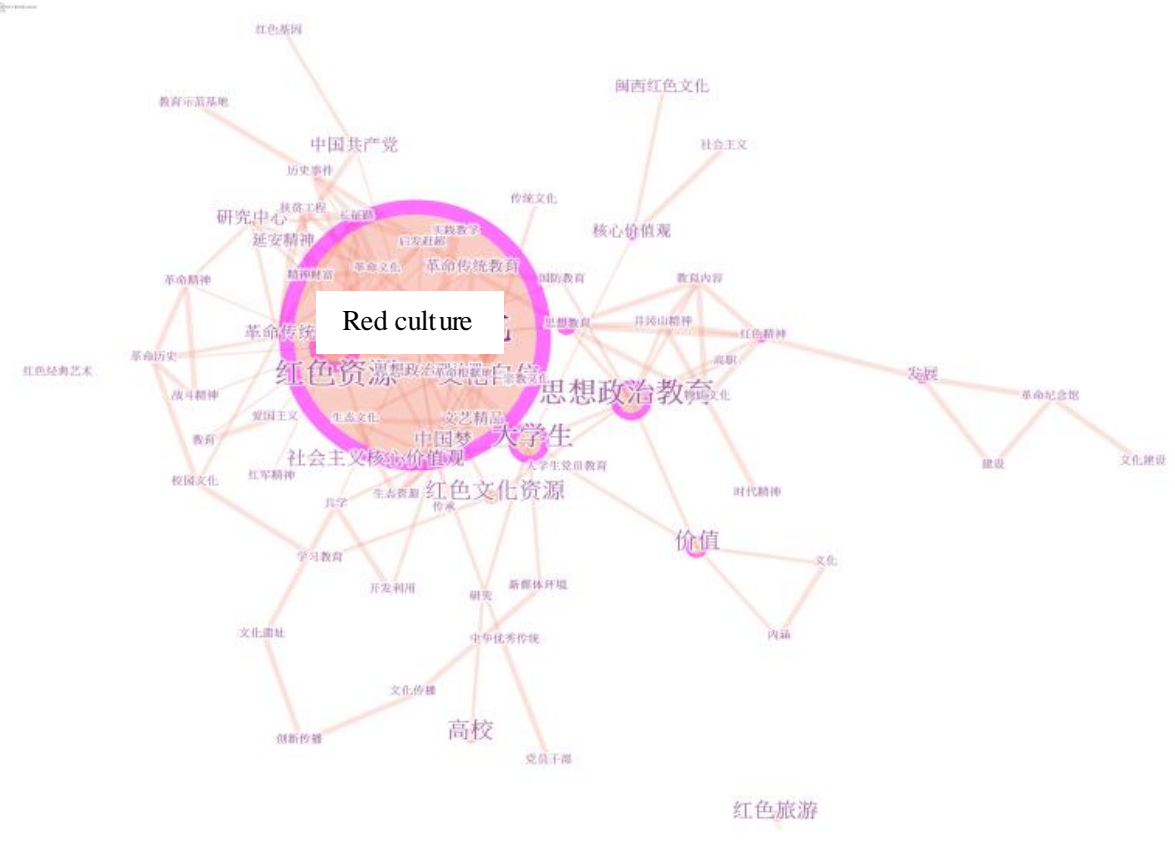

Fig. 1. A visualized analysis of keywords "red culture" based on the CNKI literat ure 
Red aesthetics is not a very clear concept in the aesthetic system. In this article, we regard it as a collection of red culture produced by revolutionary history of modern China in aesthetics. Domestic research is thorough and sufficient to the former, while the latter is very weak. In CNKI, the following analys is results can be obtained by searching the key words, such as "red culture", "red aesthetics" and "new China aesthetics" "Table I".

TABLE I. RESEARCH STATUS ANALYSIS ON RED CULTURE AND RED AESTHETICS AND RELATIVE CONTENTS

\begin{tabular}{llll}
\hline $\begin{array}{c}\text { Theme } \\
\text { publications }\end{array}$ & $\begin{array}{c}\text { Academic } \\
\text { Journals }\end{array}$ & $\begin{array}{c}\text { Newspaper } \\
\text { Media }\end{array}$ & $\begin{array}{c}\text { Master's and } \\
\text { Doctoral } \\
\text { Thesis }\end{array}$ \\
\hline Red culture & 5860 & 3553 & 524 \\
\hline Red aesthetics & 2 & 0 & 0 \\
\hline New China aesthet ics & 37 & 2 & 1 \\
\hline Red tourism & 4385 & 3522 & 497 \\
\hline
\end{tabular}

In the big scope of red culture, the relevant cultural research, ideological and political research and economic application research have already been carried out deeply. These researches define the red culture from the perspective of material and spiritual level. Material level refers to the tangible objections, such as revolutionary sites, relics and cultural relics and so on. Spiritual level mainly refers to the established institutional norm, such as revolutionary guiding principle and line, according to the principle of combining the basic principles of Marx with the concrete reality of China's revolution, construction and reform, as well as the values, ways of thinking and spirit of the time that the Communist Party of China leads the masses in the practical activities of revolution, construction and reform.(1)

We can feel the endeavors made in recent years in the excavation, collation, protection and promotion to the various revolutionary historical cultures. At present, with a respectful attitude, the use of historical and cultural resources is more cautious, and a large number of relevant policies and regulations can be followed. In the vigorous development environment, the creation of the mainstream cultural and artistic works has always followed the tradition of red aesthetics. Literary works, poems, songs, plays and other works have been created at various times. However, it is surprising that the research of aesthetic value system related to the red culture is rather lacking.

Shaanxi is a big province of revolutionary history and culture, and the aspects of research and protection have been carried out very well in recent years. In history, the revolutionary base areas, represented by Yan'an, had created a large number of red cultural works in the course of their development. In 1942, Mao Zedong delivered a speech Talks at the Yan'an Forum on Literature and Art, which marked the beginning of a new period of literature and art when new literature combined with workers, peasants, soldiers and masses "Fig. 2". Under the guidance of Mao Zedong's literary and artistic thought, many artists have gained new achievements in the aspects of shaping the image of workers, peasants and soldiers and reflecting the great revolutionary struggle, and made great breakthroughs in the nationalization and popularization of literature. The speech put forward a basic value of literary and artistic creation that literature and art should serve for workers, peasants and soldiers. Today, more than 70 years after his speech, it is urgent for us to make a systematic analysis and construct a theoretical system on the aesthetic content of the historical and cultural development of Shaanxi revolution.

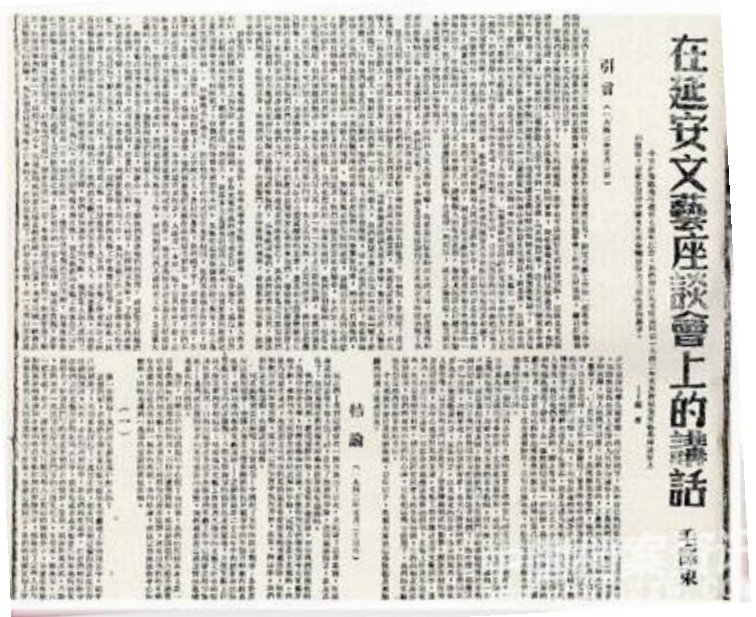

Fig. 2. Talks at the Yan'an Forum on Literature and Art was published in Liberation Daily in 1942.

\section{THE DEVELOPMENT OF THE STUDY OF RED AESTHETICS AND RELATED SOCIAL AESTHETICS:}

The researches of red culture and red aesthetics abroad are relatively fewer because of the ideological differences, however, whether the cultural origin of this topic or the depth of aesthetic research, the Soviet aesthetics is a unique representative in this field. The Soviet aesthetics is a generic term for various aesthetic thoughts of the Soviet Union, which was created at the beginning of the establishment of the Soviet regime. Under the leadership of Lenin, the Bolshevik party and the Soviet government fought against various bourgeois aesthetic thoughts and proletarian-cultural schools which denied the cultural heritage. From the middle of the 20 s to the beginning of the 30s, the Soviet Press carried out a discussion on how to establish the Marxist aesthetics and put forward a series of principles concerning the object, the boundary and the principle of aesthetics. At the same time, many main aesthetic problems were also involved in the discussion of artistic creation methods. A famous literary theorist and critic A.B.Lunacharski systematically elaborated Lenin's aesthetic thoughts, adhered to the authenticity and ideological principles of literature and art, emphasized the social function of art and advocated the creation of socialist "tragedy" and "comedy". Another literary theorist and critic В.В. Воровский (18711923) also exerted some influence on the establishment of the Soviet aesthetic thoughts. He defended the realism principles of art in many aesthetic and literary criticis $m$ articles, emphasized the tendency and the party spirit of literature and art and resolutely opposed the decadence and idealism aesthetics of Russian. Some famous writers and artists, such as 
M.Gorky, K.C.Stanislavskiy (1863-1938), C.M.Eisenstein (1898-1948), A.A.Fadeyev (1901-1956) had made a great contribution to the establishment and development of the Soviet aesthetics in the various fields, such as drama, film and literature and so on.

Since 70s, the Soviet aesthetics has developed remarkably. The research scope of aesthetics has expanded into various fields of human social activities, such as production and construction, daily life, communication activities, sports and so on, and has emerged some new aesthetics branches, such as "labor aesthetics", "technological aesthetics", and "industrial aesthetics" and so on. Since 80 s, the popularization of aes thetic education in society and the proposed new concept of "aesthetic culture" have marked the progress of aesthetic education. All these have promoted the renewal and diversification of methodology in the study of Soviet aesthetics. The Soviet aesthetics circles pay more and more attention to the interrelation and mutual penetration problems of aesthetic and artistic research with a variety of adjacent disciplines, and give more and more emphas is on adopting a variety of ways to carry out a comprehensive research of interdisciplinary and multi-angle on the basic problems of aesthetics and art. The methodologies in the Soviet aesthetics circles include epistemology method, sociology method, psychological analytical and system analytical method, value analysis method, aesthetic sociology method, art psychology method, typological analytical method, comparative historical analytical method, semiotics and semantics analytical methods, statistical methods, culture pedagogy analytical methods and so on.

At the beginning of the founding of the People's Republic of China, great attention was paid to the issue of new aesthetics and Soviet aesthetics, and a certain degree of academic researches were carried out, as shown in "Fig. 3", Soviet aesthetics issues published in the Academic Monthly magazine in 1957.

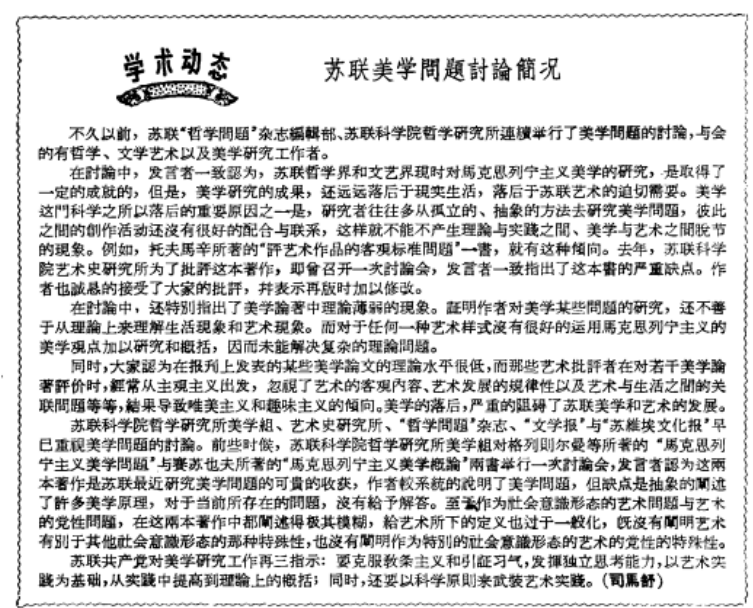

Fig. 3. The academic dynamics of the ninth issue in 1957 came out Academic Monthly. The subject is a discussion of Soviet aesthetics, and the author is Sima Shu.

\section{EXPLORATION OF AEST HETIC RESEARCH METHODS BASED ON THE REVOLUTIONARY HIST ORY AND CULTURE OF SHAANXI}

Take the revolutionary historical and cultural heritage of Shaanxi as the object of study and the influence of visual art and public aesthetics as the main research goal, and deeply excavate and extract the basic structure of the red aesthetics under the influence of Shaanxi's historical culture. The red aesthetic value contained in revolutionary historical culture has been for people to feel and use, however, the theoretical construction is not as good as the discussion of other aspects of the red culture, and there is no definite characterization of the aesthetic features embodied in the various artistic styles under the red cultural background in different periods. Therefore, it can be studied in several ways in the following ways:

1.The study of the red aesthetic thought in the early revolutionary historical culture. In the development of early revolutionary history of Shaanxi (1920s), a large number of revolutionary ideas and cultural contents needed to spread, and the means of communication also adapted to the actual demands and carried out a great deal of localization treatment in the process of localization of political thought. A large number of contents derived from the early Soviet aesthetic system must be integrated with local customs, so as to make for common people to understand. These plain and simple aesthetic creations are of great value and worth our further study and interpretation "Fig. 4".

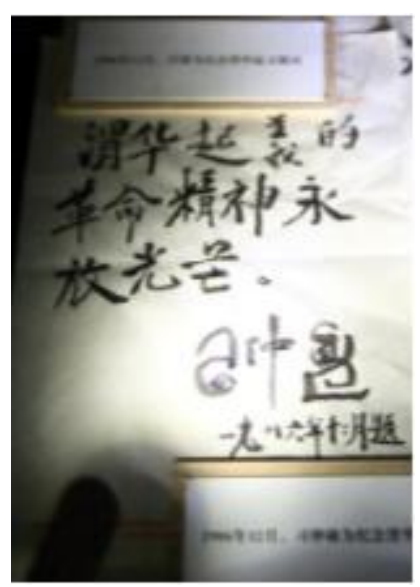

Fig. 4. In 1986, the inscription was written by $\mathrm{Xi}$ Zhongxun to commemorate the Weihua revolt and now it is collected in Zhaojin revolutionary history museum.

2. Interpretation of cultural symbols of red aesthetics in different periods. From the combination of ideological education and folk culture in the early revolutionary history of Shaanxi to the aesthetic thoughts influenced by industrial culture in the early founding of new China and then to the political pop, red aesthetic characteristics in different periods are constantly developing. Corresponding to the historical periods of politics, economy, culture and technology, the author interprets the representative aesthetic cultural symbols and re-understands the contemporary social culture "Fig. 5". 


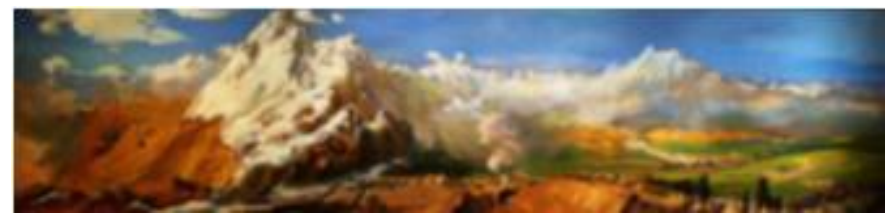

Fig. 5. Oil painting, To Unumqi, was created by the author, Ai Zhongxin, which is collected in National Art Museum of China.

3. Analyze and arrange the aesthetic genes of red culture which are permeated in the contemporary social culture and discuss the indispensable elements of the red aesthetic culture. None of us can ever be outside the social culture, and the red aesthetic gene has been deeply embedded in our cultural consciousness. By analyzing and arranging these elements, we can rationally face the increasingly globalized digital cultural environment.

4. Analyze and deconstruct the cultural introspection move ment that begins in the 80 s of the last century and a large number of literary and artistic works, and re-discover the essential influence of the red aesthetic gene on them.

5. Analyze the various properties of red aesthetics as foreign culture and local culture and contemporary culture, and compare the differences and commonalities of the artistic works constructed by these qualities in the aspects of artistic form, content, and aesthetic features and so on.

The flow chart of research method in red aesthetics theoretical fra mework."Fig. 6"

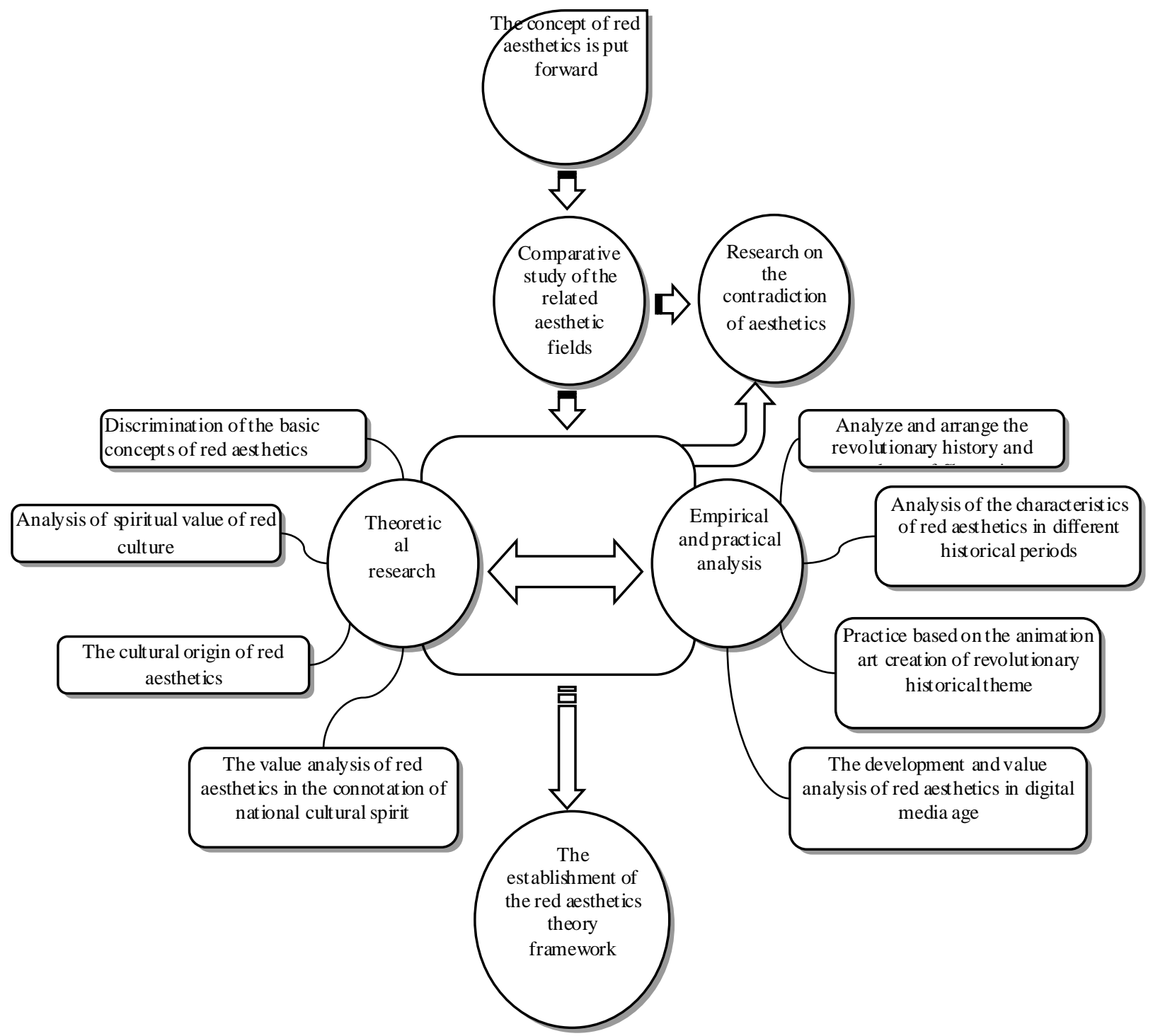

Fig. 6. THE chart of research method in red aesthetics theoretical framework. 


\section{CONCLUSION}

The red culture has become an inseparable part in Chinese traditional culture, regardless of its source and developing process, and in history, the red culture has permeated its veins into our national personality. Studying the aesthetic essence in red culture and extracting the aesthetic elements that have penetrated into the national culture is an important method to keep our cultural independence when we face with the digital era cultural fusion environment.

The most profound influence of the red culture on the national personality should be reflected in the values and aesthetic consciousness. In the land of Shaanxi, the revolutionary historical and cultural heritage can be found everywhere, and those folk culture contents which have been included into the red cultural system are still active in people's lives.

The theoretical significance of the red aesthetic framework lies in the fact that the red culture genes left in the historical development have been deeply rooted in our ideology, which is not transferred by human will. The spirit of the red culture has a special aesthetics value. This kind of red spirit not only can touch people with love, but also can arouse people's moral reason, and encourage people to conduct a moral examination and rational reflection on themselves to help people to train and rebuild their morality (2). With the development of the times, multicultural influences the traditional consciousness and also integrates with it, which also includes the red culture. People's aesthetic consciousness and values become more transparent and tolerant in the information age. Today, when the red aesthetics seems to be hidden behind the scenes, it is precisely the moment that we should pay attention to and sort out the genes.

\section{REFERENCES}

[1] Mao Zedong, Talks at the Yan' an Forum on Literature and Art[M]. Selected works of Mao Zedong. Volume Third. 1953.

[2] Xia Chunhua. Present Situation and Thinking of Red Culture Research[J]. Intelligence. April 2016.

[3] Li Xiang. The Aesthetic Value of the Red Spirit[N].Guangming Daily. Edition 11. October 26, 2013.

[4] Ling Jiyao. Soviet Contemporary Aesthetics[M]. Harbin: Heilongiiang People's Publishing House, 1986.

[5] Zhang Jiemo, Cai Jianmei. Facing with the Conversion of the Red Aesthetic[J]. A Multidimensional Study of Orientalism. March 2009.

[6] Yang Xiaobin. The Memory about "Red" in the Chinese Avant-Art[J]. China Culture and Philosophy Research Collected Papers. September 2007. Thirty-first issue.

[7] Liu Runwei. On Red Culture[J]. Theory and Criticism of Literature and Art. April 2013. 